8. Нортроп Д., Кунитц М., Херриот т Р., Кристаллические ферменты, М., 1950 , c. $121-161$.

9. Nord F. F., B i e r M., Biochim. Biophys. Acta, 12, 56 (1953)

10. He inlo H., ENSV TA Toim. Keemia. Geoloogia, 21, 176 (1972)

1.1. Иох аннес Э., Изв. АН ЭССР, Хим. Геол. 17, 167 (1968).

12. Kunitz M., J. Gen. Physiol., 30, 291 (1974).

Eesti NSV Teaduste Akadeemia Keemia Instituut
Toimetusse saabunud 12. X 1973

EESTI NSV TEADUSTE AKADEEMIA TOIMETISED. 23. KOIDE

KEEMIA * GEOLOOGIA. 1974, NR. 3

ИЗВЕСТИЯ АКАДЕМИИ НАУК ЭСТОНСКОИ ССР, ТОМ 23

ХИМИЯ * ГЕОЛОГИЯ. 1974, N.3

удК $552.578+665.452 .2$

И. КЛЕСМЕНТ, ЮТА РИККЕН, К. УРОВ, А. ВНИРЕС, О. ЭИЗЕН

\title{
СОСТАВ И ОБРАЗОВАНИЕ 4-АЛКИЛРЕЗОРЦИНОВ СМОЛЫ ПОЛУКОКСОВАНИЯ СЛАНЦА-КУКЕРСИТА
}

I. KLESMENT, JUTA RIKKEN, K. UROV, A. VIIRES, O. EISEN. KUKERSIIDI POOLKOKSISTAMISE OLI 4-ALKOOLRESORTSIINIDE KOOSSEIS JA MOODUSTUMINE

I. KLESMENT, JUTA RIKKEN, K. UROV, A. VIIRES, O. EISEN. COMPOSITION AND FORMATION OF 4-ALKYLRESORCINOLS OF SEMICARBONIZATION TAR OF OIL SHALE KUKERSITE

Эстонский горючий сланец-кукерсит отличается от всех других известных керогенсодержащих пород тем, что при его термическом разложении образуется много фенолов, особенно 5-алкилрезорцинов, количество которых составляет $5 \%$ на смолу [']. Согласно [2], 5-алкилрезорцины образуются из алифатических поли- $\beta$-карбонильных структур; в этой же работе представлена гипотетическая схема их образования. Поликарбо нильные фрагменты керогена являются продуктами изомеризации, гидратации и окисления полиненасыщенных жирных кислот [2]. Предполагаем, что они образовались вследствие окисления $\left[{ }^{3}\right]$ при седиментации исходного вещества керогена.

Следующая группа фенолов - 4-алкилрезорцины. Индивидуальный и количественный состав обеих групп показан на рисунке. Фенолы были выделены из генераторной смолы щелочью и разделены на группы методом препаративной тонкослойной хроматографии [4]. Фенолы анализировались газохроматографически на аппарате «Хром-4» с пламенно-ионизационным детектором, используя колонку $5,75 \mu \times 3$ мм с $6 \%$ апиезона $L$ на хромосорбе $P$ AW DMCS (45-60 меш).

Как явствует из рисунка, составы обеих групп изомерных резорцинов явно коррелируют между собой - их кривые распределения по длине алкильной цепи различаются тем, что 4-алкилрезорцин во всех максимумах и минимумах концентрации содержит в молекуле на один атом углерода больше, чем 5-алкилрезорцин. При образовании 5-алкилрезорцина исходное вещество - фрагмент керогена со структурой сложного эфира поли- $\beta$-карбонильной кислоты - декарбоксилируется [ $\left.{ }^{2}\right]$. Указанная корреляция может быть объяснена тем, что при образовании 4-алкилрезорцина углеродный атом карбоксильной группы остается в молекуле, образующей фенол. Представляем здесь два возможных пути образования 
4-алкилрезорцина $\left(\mathrm{R}_{1}\right.$ - нормальная алкильная цепь и $\mathrm{R}$ - циклическое ядро макромолекулы көрогена):

$$
\begin{aligned}
& \mathrm{R}_{1}-\mathrm{CH}_{2}-\mathrm{CO}-\mathrm{CH}_{2}-\mathrm{CO}-\mathrm{CH}_{2}-\mathrm{CO}-\mathrm{O}-\mathrm{R} \longrightarrow \\
& \mathrm{R}_{1}-\mathrm{CH}_{2}-\mathrm{CO}-\mathrm{CH}_{2}-\mathrm{CO}-\mathrm{CH}_{2}-\mathrm{CO}-\mathrm{R}
\end{aligned}
$$

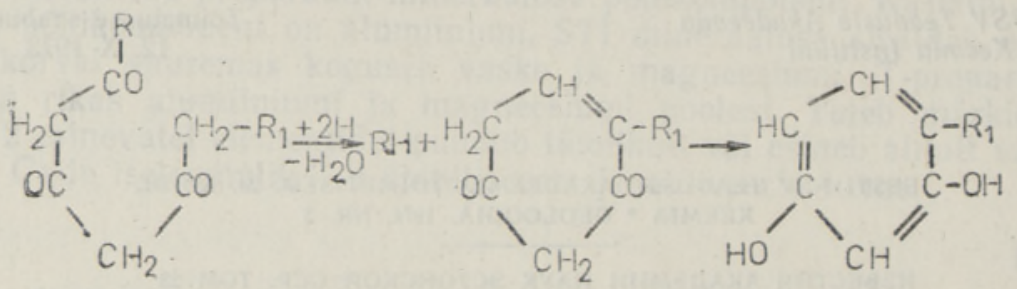

По первой схеме сложноэфирная связь превращается при фоссилизации в углерод-углеродную связь (реакция 1). Эта реакция может проходить подобно перегруппировке Фриза [5]. Далее следует циклизация по механизму альдольной конденсации, отщепление цикла от ядра керогена и таутомерное превращение в фенол (реакция 2). Последние реакции протекают, вероятно, в процессе термического разложения.

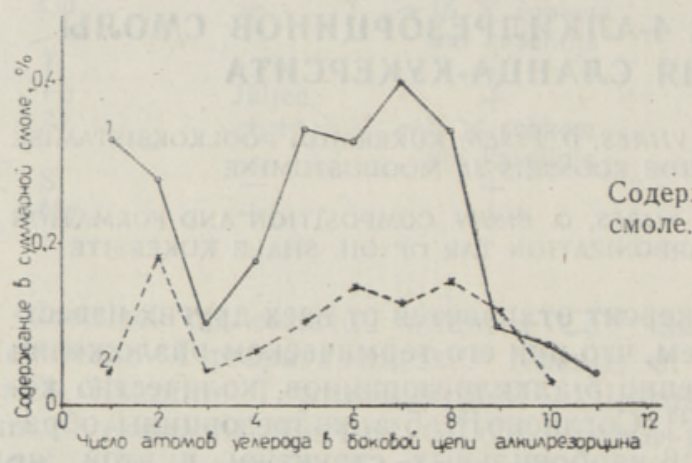

Содержание алкилрезорцинов в генераторной моле. 1 - 5-алкилрезорцины, $2-4$-алкилрезорцины.

По второй схеме сложноэфирная группа восстанавливается в полуацетальную группу, которая легко диссоциируется с образованием альдегида:

$$
-\mathrm{CO}-\mathrm{O}-\mathrm{R} \stackrel{+2}{\longrightarrow}-\mathrm{CH}(\mathrm{OH})-\mathrm{O}-\mathrm{R} \rightleftarrows-\mathrm{CHO}+\mathrm{HO}-\mathrm{R}
$$

Циклизация альдегида в дикетон аналогично реакции 2 проходит даже легче, чем в случае кетонной промежуточной формы. Для протекания реакции по обеим схемам требуется водород, источником которого может являться циклическое ядро керогена.

\section{Л ИТЕРА Т Р Р А}

1. Л илл е Ю. Э., Исследования в области алкилрезорцинов. Автореферат, Таллин, 1973.

2. К лесм ен т Й. Р., Химия твердого топлива, № 2, 33 (1973).

3. Д а в и т а ш в и ли Л. Ш., Эволюция условий накопления горючих ископаемых в связи с развитием органического мира, М., 1971, с. 210.

4. В а хе сс а а р В., Кл есм ен т И., Э й зен О., Изв. АН ЭССР, Хим. Геол., 18, 341 (1969).

5. К а р ре р П., Курс органической химии, Л., 1960, с. 633.

Ннститут химии

Академии наук Эстонской ССР

НИИ сланцев
Поступила в редакцию 26/XI 1973 